\title{
Student Acceptance of Knowledge Management Systems: Evidence from a Canadian Business School
}

\author{
Muhammad Muazzem Hossain ${ }^{1}$, Noufou Ouedraogo ${ }^{2} \&$ Davar Rezania $^{3}$ \\ ${ }^{1}$ Dept. of Supply Chain \& Decision Sciences, School of Business, MacEwan University, Edmonton, Canada \\ ${ }^{2}$ Dept. of OB/HR, School of Business, MacEwan University, Edmonton, Canada \\ ${ }^{3}$ Department of Business, University of Guelph, Guelph, Canada
}

Correspondence: Muhammad Muazzem Hossain, Dept. of Supply Chain \& Decision Sciences, School of Business, MacEwan University, Edmonton, AB., T5J 4S2, Canada. Tel: 1-780-633-3514. E-mail: HossainM4@macewan.ca

$\begin{array}{lc}\text { Received: March 19, } 2013 & \text { Accepted: April 22, } 2013 \quad \text { Online Published: May 14, } 2013 \\ \text { doi:10.5539/ijbm.v8n12p29 } & \text { URL: http://dx.doi.org/10.5539/ijbm.v8n12p29 }\end{array}$

\begin{abstract}
This study investigates the factors affecting the perceived usefulness of and the intention to use knowledge management (KM) systems by students. The research model posits that the intention to use KM systems in higher education depends on perceived usefulness, perceived user-friendliness, organizational rewards, and community of practice. A survey method was used to collect the data for the study. We used a convenience sample consisting of undergraduate students enrolled in various business courses in a Canadian University. The data obtained from a sample of 120 students were initially factor analyzed to identify the relevant factors. Separate factor analysis was conducted for each of three types of measures - the independent measures, the intermediate measures, and the dependent measure. In order to test the proposed hypotheses, we employed the method of multiple regression analysis. The findings suggest that organizational rewards and KM system characteristics positively impact perceived usefulness, and that user-friendliness, usefulness, organizational rewards, and community of practice are significant predictors of intention to use KM system. This analysis reveals that business schools need to focus on usefulness and practical relevance of knowledge captured in knowledge management systems. This is in line with the current debate in management education regarding the appropriateness of methods employed to teach business knowledge. Organizational rewards being a significant predictor of intention to use KM systems corroborate the expectancy theory. Therefore, it is important for business schools to communicate on the usefulness of their KM systems but also to encourage its usage through different incentives.
\end{abstract}

Keywords: business school, knowledge management system, intention to use, technology acceptance model, expectancy theory

\section{Introduction}

Organizations employ knowledge management (KM) systems to leverage their knowledge resources in order to sustain competitive advantage in volatile environments (Kankanhalli, Tan \& Wei, 2005). KM systems are "a class of information systems applied to managing organizational knowledge. That is, they are IT-based systems developed to support and enhance the organizational processes of knowledge creation, storage/retrieval, transfer, and application" (Alavi \& Leidner, 2001, p. 114). A plethora of knowledge management frameworks have been developed to link disparate knowledge resources to a value creating business purpose (Massey, Durand \& Malone, 2002). A few studies have investigated the use KM in non-traditional settings such as the nonprofit sector (Tan \& Al-Hawamdeh, 2001), higher education (Chua \& Heng, 2010; Arntzen, Worasinchai \&Ribiere, 2009; Rowley, 2000), museums (Hansen \& Moussouri, 2004), creative advertising industry (Ensor, Cottam \& Band, 2001), and cultural villages (Mearns \& du Toit, 2008). KM in most of these settings has been found largely to be a serendipitous effort (Chua \& Heng, 2010).

Knowledge creation, application, and dissemination are at the core of any business school's mission. As such, it is of crucial importance to a business school to develop the capacity to maintain and renew its knowledge. Even though universities have been creating, preserving and passing knowledge from generation to generation, in the 
0contemporary dynamic and complex environment, the scope and content of knowledge have changed dramatically, often as a result of spread of information technology and the Internet. KM is multidisciplinary in nature and embodies three major themes - the technocentric theme, the organizational theme, and the ecological theme (Chua \& Heng, 2010). These themes pertain to three major components of a process-oriented KM strategy - technology, process, and people - respectively. The technocentric theme is concerned with the use of technology to enhance knowledge creation and transfer (e.g., Johannessen, Olaisen \& Olsen, 2001). The organizational theme deals with how an organization can be designed to promote knowledge processes (e.g., Davenport, De Long \& Beers, 1998). The ecological theme of KM strategy focuses on the interaction among people, their identities and the environment (e.g., Wenger \& Snyder, 2000; Kimble \& Bourdon, 2008). Due to the versatility of KM and its focus on how knowledge is developed and refined in social contexts, KM systems are increasingly gaining recognition as enabling higher education to evolve to a highly interactive and dynamic educational environment (Arntzen et al., 2009; Chua \& Heng, 2010). In spite of the theoretical potential of using KM systems, the success of these systems depends on its effective use by the users. Thus, in business schools, the acceptance of KM systems by students is a precondition for the realization of KM systems' potentials. Despite a wealth of literature on the ontology of knowledge in business education, our search of large databases, such as EBESCO using search terms such as "knowledge management and business schools" resulted only in a handful of articles pertaining to the use of KM systems in higher education institutions. A review of the literature related to KM suggests that there has been little or no research on the adoption of KM systems by students in business schools. In this study, we investigate the factors that influence the acceptance of and the motivation to use KM systems by Canadian business students by presenting evidence from a business in Western Canada.

The rest of the paper is organized as follows. Next section describes the relevance of knowledge management to business schools of higher education and provides the theoretical foundation of the study. Section 3 presents the research model and the proposed hypotheses. The methodology for the study is discussed in Section 4. The data analysis and results are highlighted in Section 5. Finally, Section 6 sheds light on the discussion, limitations, and future direction of the study.

\section{Literature Review}

\subsection{Knowledge Management and Its Relevance to Business Schools}

Despite, or perhaps because of, the steady growth of business programs and business schools, such programs are facing significant discussion around the rigor, practical relevance and the appropriateness of methods they use to prepare business students for their future challenge as managers and leaders of our organizations (Chia, 2005; Donaldson, 2002; Ghoshal, 2005; Leavitt, 1989; Mintzberg \& Gosling, 2002; Pfeffer \& Fong, 2002; Pfeffer, 2007; Rubin \& Dierdorff, 2009). Students are being trained to break and address complex and ambiguous problems in functional silos such as finance, HR, and marketing (Pfeffer \& Fong, 2002). This approach to business education might have been sufficient in an era when organizations were organized in terms of functions. However, changes in the business environment have outdated functional organization of work and resulted in other forms of organizational structures (West \& Altink, 1996). Such forms include, but are not limited to, organizing in teams (Katzenbach \& Smith, 1993), organizing in networks (Pearce, 2004; Pearce, Conger \& Locke, 2007), and organizing across customers or processes (Turner, 1999). This change is yet not reflected in management education (Feldman, 2005). Development of abilities for independent critical and adaptive thinking as well as development of interpersonal skills has not been receiving sufficient attention (Boyatzis, 1982; Chia, 2005; Fenwick, 2005). In addition to the above demands relating to the content of management research focus, curriculum, and the teaching methods, business schools are facing increasing life-long learning demands, and the increasing learning needs of adults with nontraditional educational backgrounds (Final Report of the Alberta MLA Committee on Lifelong Learning, 2002; Rezania and Henry, 2010).

At the heart of the discussion lies both the nature and the impact of formal knowledge realized through management research and teaching (Chia, 2005; Chia \& Holt, 2008). On one side of the continuum, the acquisition of knowledge and skills is seen as objectively measurable, aggregative, context-independent, and transferable (Trowler, 1996). On the other side of the continuum, knowledge and understanding are viewed as socially constructed by individuals, integrated into their cognitive structures derived from particular experiences and ways of seeing things (Glaser, 1984; Trowler, 1996). This distinction has been manifested in the works of Piaget and Vigotsky (Piaget, 1962). Various terms are used to express the notion of this continuum: Procedural Knowledge (knowledge of formal language or symbolic representations - knowledge of rules, algorithms, and procedures) versus Conceptual or Propositional Knowledge (knowledge rich in relationships and understanding, a connected web of knowledge, a network in which the linking relationships are as prominent as the discrete bits 
of information) (Papert, 1980), or explicit versus tacit knowledge (Polanyi, 1966).

Whatever view we choose, KM systems have a place in business schools, as they comprise four sets of knowledge processes. These processes are: construction, storage and retrieval, distribution, and application (Alavi \& Liedner, 2001; Huber, 1991). Our pedagogy is affected by our view of knowledge (Glaser, 1984; Trowler, 1996). The way we organize the curriculum and the teaching methods depends on whether we view knowledge and understanding as socially constructed by individuals, or being independent of individual differences (Badawy, 1976; Dewey, 1896; Martínez, Toyne \& Menger, 2000; Palincsar, 1998). Business schools have been focusing on knowledge by representation (Chia \& Holt, 2008). However, the workplace requires more relevant knowledge from business graduates (Feldman, 2005; Ghoshal, 2005; Mintzberg \& Gosling, 2002). Therefore, business schools face the challenge of creating and disseminating more practical, relevant, and contextual knowledge (Birnik \& Billsberry, 2008). Various constituents, including faculty, students, and the companies looking to hire business graduates have their own objectives and expectations (Birnik \& Billsberry, 2008). In addition, business schools are faced with the globalization of work and careers, the evolution of society into a knowledge economy (Friga, Bettis, \& Sullivan, 2003).

The study of KM systems is relevant in the debate concerning business education because such systems are related to the transfer of knowledge where it is most needed and help organizations in the application of the knowledge (Nonaka \& Konno, 1998). KM systems, which are often coupled with quality management initiatives (Lambert \& Ouedraogo, 2006), help an organization identify the existing knowledge, skills, and competence, evaluate and codify them and become a learning organization (Argyris \& Schön, 1978; Argyris, 1982; Cowan, David \& Foray, 2000; Cohendet \& Meyer-Krahmer, 2001; Lambert \& Lerch, 1999; Bénézech, Lambert, Lerch, Loos-Baroin, 2001; Ouedraogo, 2007). Transferring knowledge from the individual to the whole organization is a challenge (Kim, 1993) and knowledge codification can partially address this challenge. KM systems help to create new knowledge, best practices and competences, through communities of practice (Brown \& Duguid, 1991; Cataldo, 2009), mentorship programs, companionship programs, organization-wide suggestions for improvement programs (Cannon \& Witherspoon, 2005; Ellis \& Davidi, 2005), and orientation and training programs (Lin \& Wu, 2005). Business schools may use technology oriented knowledge management like the intranets and other software to share some explicit knowledge and work instructions. This technology approach complements other socially oriented knowledge management practices like communities of practice, mentorship, companionship that are more appropriate in conveying tacit knowledge, competence and talent (Lambert \& Ouedraogo, 2007).

\subsection{Theoretical Foundation}

A review of the extant literature suggests that KM systems have been widely studied in the past several years (e.g., Cortada \& Woods, 2000; Gray, 2000; Alavi \& Leidner, 2001; Xu \& Quaddus, 2005a, 2005b). Xu and Quaddus (2005a, 2005b) have utilized and validated the technology acceptance model for use with the knowledge management systems. They suggest that the spread and use of KM systems depends on a number of factors that includes perceived usefulness and perceived user-friendliness. They also posit that several external factors impact perceived usefulness of KM systems. Within the context of higher education, these external factors can be combined into three factors, namely, individual factors, management support, and KM system characteristics.

Our research model is based on the technology acceptance model (Davis, 1986; Davis, Bagozzi \& Warshaw, 1989) combined with the expectancy theory model (Vroom, 1964). According to the technology acceptance model, a technology is more likely to be accepted if an organization and/or an individual perceive that it is usefulness and if the technology is easy to use by them (user-friendliness). Although this model by its own may be sufficient in some circumstances, it is important to stress that organizations also motivate their members to adopt a technology by using different incentives. In the case of a business school, any system use that is rewarded by the organization is more likely to be adopted and used by students. To capture this concept of organizational reward and its importance on the intention to use knowledge management systems, we used the expectancy theory. According to Vroom, motivation is higher when an individual perceives that his/her efforts will result in a performance which is rewarded by the organization and that this reward responds to the individual's needs. With the intent to motivate its members, an organization can reward those who adopt and promote organizational systems to better their performances. Thus, organizational rewards induce the adoption of a system if the system results in performance improvement. The same reasoning applies to students' intention to use knowledge management systems in higher education. 


\section{Reseach Model and Hypotheses}

Consistent with the theoretical foundation, we propose the research model depicted in Figure 1. The model posits that the intention to use KM system in higher education depends on perceived usefulness, perceived user-friendliness, organizational rewards, and community of practice. Based on the relevant literature in knowledge management systems (e.g., Xu \& Quaddus, 2005a, 2005b), we also propose that individual factors, management support, and KM system characteristics have an impact on perceived usefulness. Table 1 summarizes the research constructs for this study.

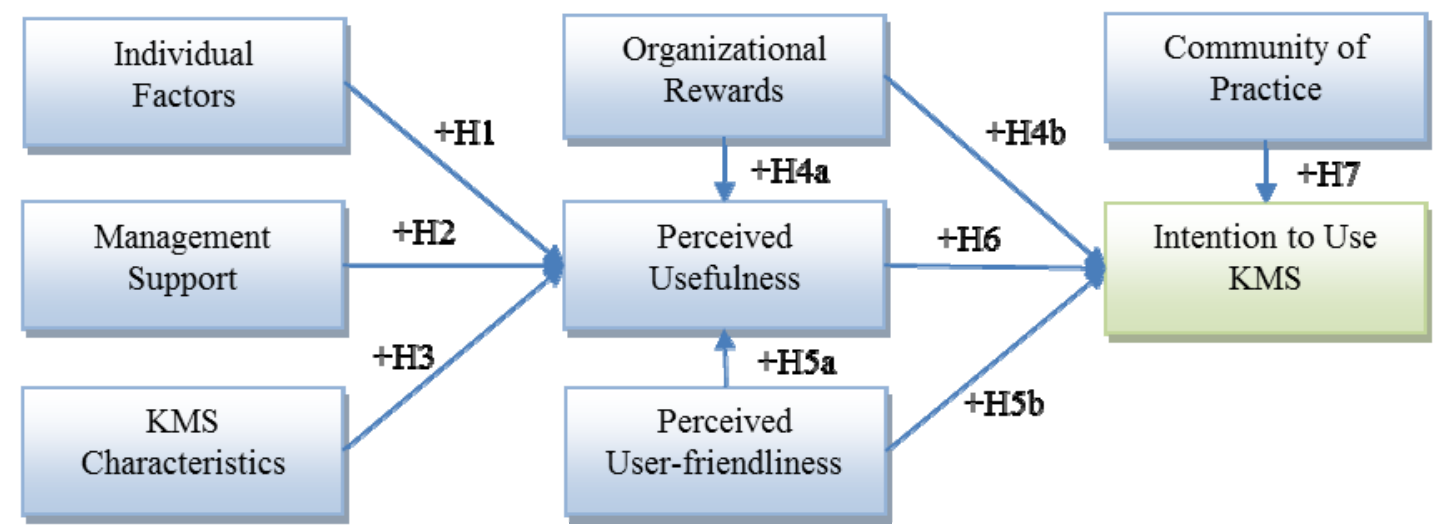

Figure 1. Factors affecting the usefulness of and intention to use KM system in business schools

Table 1. Summary of constructs

\begin{tabular}{|c|c|c|}
\hline Constructs & Definition & Source \\
\hline Individual Factors & $\begin{array}{l}\text { Factors such as experience and skills of using } \\
\text { KM system, personal innovativeness, positive } \\
\text { attitude towards KM system, etc. }\end{array}$ & $\begin{array}{l}\text { Adapted from Xu and } \\
\text { Quaddus (2005a, 2005b) }\end{array}$ \\
\hline Management Support & $\begin{array}{l}\text { Support students can obtain from management } \\
\text { regarding the use of KM system. }\end{array}$ & $\begin{array}{l}\text { Adapted from Xu and } \\
\text { Quaddus (2005a, 2005b) }\end{array}$ \\
\hline $\begin{array}{ll}\text { KM } & \text { System } \\
\text { Characteristics } & \end{array}$ & $\begin{array}{l}\text { Factors such as KM system security, KM } \\
\text { system accessibility, KM system providing } \\
\text { what students need. }\end{array}$ & $\begin{array}{l}\text { Adopted from Xu and } \\
\text { Quaddus (2005a, 2005b) }\end{array}$ \\
\hline Organizational Rewards & $\begin{array}{l}\text { Organizational incentives to motivate its } \\
\text { members based on their performance }\end{array}$ & Adapted from Vroom (1964) \\
\hline Perceived Usefulness & $\begin{array}{l}\text { The extent to which a student believes that } \\
\text { using a KM system would provide fitness of } \\
\text { performing a task or fulfilling a requirement as } \\
\text { of time and place (Hossain \& Prybutok, 2008). }\end{array}$ & $\begin{array}{l}\text { Adapted from Davis (1986), } \\
\text { Xu and Quaddus (2005a, } \\
\text { 2005b), and Hossain and } \\
\text { Prybutok (2008) }\end{array}$ \\
\hline $\begin{array}{l}\text { Perceived } \\
\text { User-friendliness }\end{array}$ & $\begin{array}{l}\text { The extent to which a student believes that } \\
\text { using KM system would be comfortable and } \\
\text { free of effort. }\end{array}$ & Adapted from Davis (1986) \\
\hline Community of Practice & $\begin{array}{l}\text { Shared interests to improve performance by } \\
\text { helping each other. }\end{array}$ & $\begin{array}{l}\text { Adapted from Lave and } \\
\text { Wenger (1991) }\end{array}$ \\
\hline $\begin{array}{l}\text { Intention to Use KM } \\
\text { System }\end{array}$ & The likelihood to use KM system in the future & $\begin{array}{l}\text { Adapted from Hossain and } \\
\text { Prybutok (2008) }\end{array}$ \\
\hline
\end{tabular}

The factors and variables affecting the usefulness of KM system and the intention to use KM system are presented in the first column of Table 2 and Table 3. Based on the research model presented in Figure 1, we 
propose the following hypotheses:

H1: Individual factors have a positive influence on perceived usefulness.

H2: Management support has a positive influence on perceived usefulness.

H3: KM system characteristics have a positive influence on perceived usefulness.

H4a: Organizational rewards have a positive influence on perceived usefulness.

H4b: Organizational rewards have a positive influence on intention to use KM system.

H5a: Perceived user-friendliness has a positive influence on perceived usefulness.

H5b: Perceived user-friendliness has a positive influence on intention to use KM system.

H6: Perceived usefulness has a positive influence on Intention to use KM system.

H7: Community of practice has a positive influence on intention to use KM system.

\section{Methodology}

To study the intention to use knowledge management systems, we are using a hypothetico- deductive method. Based on our model, a survey method was used to collect the data for the study. The survey questionnaire had 48 questions pertaining to the different independent and dependant variables.

We used a convenience sample consisting of 131 undergraduate students enrolled in various business courses in a Canadian University. The respondents are, for the most part, in their second year, so they have experience using the knowledge management systems in the school of business. We used a 5 points Likert scale for the questionnaire with $1=$ strongly disagree and 5 strongly agree. The questionnaire was administered during class time. Students were told the objectives of our research and that filling out the questionnaire is voluntary and anonymous. There weren't any promises (mark, financial reward or the like) offered to students for filling them out. Out of 131 responses, we had 120 usable responses after deleting 11 incomplete responses.

\section{Data Analyses and Results}

\subsection{Factor Analyses}

The data were initially factor analyzed to identify the relevant factors. Separate factor analysis was conducted for each of three types of measures - the independent measures, the intermediate measures, and the dependent measure. The items loaded into factors as expected based on the theory. The cross-loadings were within the acceptable level $(<0.40)$ (Hair et al., 2006). The results of the factor analyses for independent measures, intermediate constructs, and dependent measures are shown in Table 2, Table 3, and Table 4, respectively.

Table 2. Rotated component matrix: Independent variables

\begin{tabular}{|c|c|c|c|c|c|}
\hline \multirow[b]{2}{*}{ Items } & \multicolumn{5}{|c|}{ Component } \\
\hline & 1 & 2 & 3 & 4 & 5 \\
\hline \multicolumn{6}{|l|}{ 1. Individual Factors (IF) } \\
\hline IF2: I like to try new computer technology & 0.815 & & & & \\
\hline IF6: I like computer technology & 0.798 & & & & \\
\hline IF1: I have an interest in learning computer technology & 0.784 & & & & \\
\hline IF5: I have the ability to learn computer technology & 0.752 & & & & \\
\hline IF3: I have experience using computer technology & 0.652 & & & & \\
\hline \multicolumn{6}{|l|}{ 2. Organizational Rewards (ORR) } \\
\hline $\begin{array}{l}\text { OR3: Using my university technology systems makes my } \\
\text { learning easy }\end{array}$ & & 0.842 & & & \\
\hline $\begin{array}{l}\text { OR2: Using my university technology systems makes my } \\
\text { learning interesting }\end{array}$ & & 0.781 & & & \\
\hline $\begin{array}{l}\text { OR1: Using my university technology systems helps me get } \\
\text { good grades }\end{array}$ & & 0.780 & & & \\
\hline $\begin{array}{l}\text { OR4: My university technology systems help me interact } \\
\text { with my peers }\end{array}$ & & 0.693 & & & \\
\hline
\end{tabular}




\begin{tabular}{|c|c|c|c|c|c|}
\hline 3. Management Support (MS) & & & & & \\
\hline $\begin{array}{l}\text { MS3: My university has a team of experienced technical } \\
\text { people }\end{array}$ & & & 0.812 & & \\
\hline $\begin{array}{l}\text { MS1: I get the help I need from my university Technology } \\
\text { Help Desk }\end{array}$ & & & 0.799 & & \\
\hline $\begin{array}{l}\text { MS2: My university offers the training I need to use its } \\
\text { technological systems }\end{array}$ & & & 0.793 & & \\
\hline $\begin{array}{l}\text { MS4: My university takes initiatives to help me with any } \\
\text { issue I may have }\end{array}$ & & & 0.767 & & \\
\hline 4. Community of Practice (CP) & & & & & \\
\hline $\begin{array}{l}\text { CP5: It is important that my university's School of Business } \\
\text { promotes interaction between students and instructors }\end{array}$ & & & & 0.830 & \\
\hline $\begin{array}{l}\text { CP6: It is important that my university's School of Business } \\
\text { promotes interaction among students }\end{array}$ & & & & 0.819 & \\
\hline $\begin{array}{l}\text { CP4: It is important that my university's School of Business } \\
\text { has a suggestion system to collect students' feedback }\end{array}$ & & & & 0.707 & \\
\hline $\begin{array}{l}\text { CP7: It is important that my university's School of Business } \\
\text { promotes interaction among instructors }\end{array}$ & & & & 0.706 & \\
\hline 5. KM System Characteristics (KC) & & & & & \\
\hline KC6: I am satisfied with the services provided by it & & & & & 0.751 \\
\hline KC5: I find all I need from it & & & & & 0.743 \\
\hline $\mathrm{KC} 1$ : I can access it online from anywhere & & & & & 0.697 \\
\hline $\mathrm{KC} 2$ : I feel secure using it & & & & & 0.582 \\
\hline Mean & 3.982 & 3.484 & 3.598 & 4.285 & 4.274 \\
\hline Standard Deviation & 0.910 & 0.983 & 0.932 & 0.754 & 0.914 \\
\hline Cronbach's Alpha & 0.844 & 0.857 & 0.833 & 0.789 & 0.720 \\
\hline
\end{tabular}

Table 3. Rotated component matrix: Intermediary variables

\begin{tabular}{lccc}
\hline \multicolumn{1}{c}{ Items } & \multicolumn{2}{c}{ Component } \\
\cline { 2 - 4 } 1. Perceived User-friendliness (PUF) & 1 & 2 \\
\hline PUF2: It is simple to learn and use & & \\
PUF3: It is easy to get information and knowledge & from & $\mathbf{0 . 8 2 4}$ \\
PUF1: I am able to get what I want from it & $\mathbf{0 . 8 1 7}$ \\
PUF6: It is cheap to learn and use & $\mathbf{0 . 7 9 2}$ \\
PUF4: It provides flexibility & $\mathbf{0 . 7 3 2}$ \\
\hline 2. Perceived Usefullness (PU) & $\mathbf{0 . 6 3 5}$ \\
\hline PU6: It reduces cost and time of information access and use & \multicolumn{3}{c}{} \\
PU5: It enhances learning productivity & \multicolumn{3}{c}{$\mathbf{0 . 8 4 0}$} \\
PU4: It provides high-tech image & \multicolumn{3}{c}{$\mathbf{0 . 8 0 5}$} \\
\hline Mean & $\mathbf{0 . 3 0 3}$ & $\mathbf{0 . 6 4 4}$ \\
Standard Deviation & $\mathbf{4 . 3 3 3}$ & $\mathbf{4 . 0 0 5}$ \\
Cronbach's Alpha & $\mathbf{0 . 8 0 1}$ & $\mathbf{1 . 0 6 3}$ \\
\hline
\end{tabular}


Table 4. Rotated component matrix: Dependent variable

\begin{tabular}{lc}
\hline \multicolumn{1}{c}{ Items } & Component \\
\cline { 2 - 2 } & \multicolumn{1}{c}{1} \\
\hline 1. Intention to Use KM System (ITU) & $\mathbf{0 . 8 2 8}$ \\
\hline ITU1: I am ALWAYS comfortable using my university technology systems & $\mathbf{0 . 7 5 7}$ \\
RITU3: I am NEVER comfortable using my university technology systems & $\mathbf{0 . 7 3 8}$ \\
ITU4: I am ALWAYS willing to use my university technology systems & $\mathbf{0 . 6 2 3}$ \\
RITU6: I am NEVER willing to use my university technology systems & $\mathbf{3 . 5 4 5}$ \\
\hline Mean & $\mathbf{1 . 0 1 4}$ \\
Standard Deviation & $\mathbf{0 . 7 2 2}$ \\
Cronbach's Alpha & \\
\hline
\end{tabular}

\subsection{Reliability and Validity}

We used Cronbach's alpha to check the reliability of the factors. A Cronbach's alpha of 0.65 or higher (Nunnally, 1978) was used as an acceptable value for internal consistency of the measures. The Cronbach's alphas for all the measures including the dependent variable, independent variables, and intermediate variables range from 0.720 to 0.857 . These values support the contention that all the factors had adequate reliability. The reliabilities of the factors are shown in Tables 2, 3, and 4. In this study, we examined the item-total correlations to ensure that the factors have acceptable convergent validity. A factor has adequate convergent validity if all of its item-total correlations equal or exceed the recommended criterion of 0.40 (Jayanti \& Burns, 1998). Table 5 shows that all item-total correlations of the variables are more than the recommended criterion of 0.40 . This supports the contention that the scales have adequate levels of convergent validity. The across factor correlations were then compared to the reliabilities of the scales to check whether the scales displayed adequate discriminant validity (Gaski \& Nevin, 1985). A construct has an adequate level of discriminant validity if the reliability of the construct is higher than the correlations between that construct and any other construct (Gaski \& Nevin, 1985). Table 6 shows that the scales also have adequate levels of discriminant validity.

Table 5. Scale reliability and convergent validity

\begin{tabular}{|c|c|c|}
\hline & $\begin{array}{l}\text { Corrected Item-Total } \\
\text { Correlation }\end{array}$ & $\begin{array}{l}\text { Cronbach's } \\
\text { Alpha }\end{array}$ \\
\hline \multicolumn{3}{|l|}{ Independent Variables } \\
\hline 1. Individual Factors (IF) & & 0.844 \\
\hline IF2: I like to try new computer technology & 0.764 & \\
\hline IF6: I like computer technology & 0.720 & \\
\hline IF1: I have an interest in learning computer technology & 0.686 & \\
\hline IF5: I have the ability to learn computer technology & 0.596 & \\
\hline IF3: I have experience using computer technology & 0.523 & \\
\hline 2. Organizational Rewards (ORR) & & 0.857 \\
\hline $\begin{array}{l}\text { OR3: Using my university technology systems makes my learning } \\
\text { easy }\end{array}$ & 0.782 & \\
\hline $\begin{array}{l}\text { OR2: Using my university technology systems makes my learning } \\
\text { interesting }\end{array}$ & 0.737 & \\
\hline $\begin{array}{l}\text { OR1: Using my university technology systems helps me get good } \\
\text { grades }\end{array}$ & 0.760 & \\
\hline $\begin{array}{l}\text { OR4:My university technology systems help me interact with my } \\
\text { peers }\end{array}$ & 0.538 & \\
\hline
\end{tabular}




\begin{tabular}{|c|c|c|}
\hline 3. Management Support (MS) & & 0.833 \\
\hline MS3: My university has a team of experienced technical people & 0.703 & \\
\hline $\begin{array}{l}\text { MS1: I get the help I need from my university Technology Help } \\
\text { Desk }\end{array}$ & 0.637 & \\
\hline $\begin{array}{l}\text { MS2: My university offers the training I need to use its } \\
\text { technological systems }\end{array}$ & 0.693 & \\
\hline $\begin{array}{l}\text { MS4: My university takes initiatives to help me with any issue I } \\
\text { may have }\end{array}$ & 0.664 & \\
\hline 4. Community of Practice (CP) & & $\mathbf{0 . 7 8 9}$ \\
\hline $\begin{array}{l}\text { CP5: It is important that my university's School of Business } \\
\text { promotes interaction between students and instructors }\end{array}$ & 0.703 & \\
\hline $\begin{array}{l}\text { CP6: It is important that my university's School of Business } \\
\text { promotes interaction among students }\end{array}$ & 0.659 & \\
\hline $\begin{array}{l}\text { CP4: It is important that my university's School of Business has a } \\
\text { suggestion system to collect students' feedback }\end{array}$ & 0.510 & \\
\hline $\begin{array}{l}\text { CP7: It is important that my university's School of Business } \\
\text { promotes interaction among instructors }\end{array}$ & 0.543 & \\
\hline 5. KM System Characteristics (KC) & & 0.72 \\
\hline KC6: I am satisfied with the services provided by it & 0.669 & \\
\hline KC5: I find all I need from it & 0.603 & \\
\hline $\mathrm{KC} 1$ : I can access it online from anywhere & 0.478 & \\
\hline $\mathrm{KC} 2$ : I feel secure using it & 0.414 & \\
\hline
\end{tabular}

\begin{tabular}{lll}
\hline \multicolumn{3}{c}{ Intermediate Variables } \\
\hline 1. Perceived User-friendliness (PUF) & & $\mathbf{0 . 8 4 9}$ \\
\hline PUF2: It is simple to learn and use & 0.726 & \\
PUF3: It is easy to get information and knowledge from & 0.752 & \\
PUF1: I am able to get what I want from it & 0.726 & \\
PUF6: It is cheap to learn and use & 0.555 & $\mathbf{0 . 7 2}$ \\
PUF4: It provides flexibility & 0.543 & \\
\hline 2. Perceived Usefulness (PU) & & \\
\hline PU6: It reduces cost and time of information access and use & 0.545 \\
PU5: It enhances learning productivity & 0.566 & \\
PU4: It provides high-tech image & 0.464 & \\
\hline
\end{tabular}

\section{Dependent Variable}

\begin{tabular}{lc}
\hline 1. Intention to Use KM System (ITU) & $\mathbf{0 . 7 2 2}$ \\
\hline $\begin{array}{l}\text { ITU1: I am ALWAYS comfortable using my university technology } \\
\text { systems }\end{array}$ & 0.472 \\
$\begin{array}{l}\text { RITU3: I am NEVER comfortable using my university technology } \\
\text { systems }\end{array}$ & 0.424 \\
$\begin{array}{l}\text { ITU4: I am ALWAYS willing to use my university technology } \\
\text { systems }\end{array}$ & 0.553 \\
$\begin{array}{l}\text { RITU6: I am NEVER willing to use my university technology } \\
\text { systems }\end{array}$ & 0.564 \\
\hline
\end{tabular}


Table 6. Discriminant validity of the constructs

\begin{tabular}{cccccccr}
\hline & PUF & PU & IF & ORR & MS & CP & KC \\
\hline PUF & $0.849^{*}$ & & & & & & \\
PU & 0.549 & 0.720 & & & & & \\
IF & 0.089 & 0.205 & 0.844 & & & & \\
ORR & 0.272 & 0.487 & 0.320 & 0.857 & & & \\
MS & 0.300 & 0.368 & 0.158 & 0.364 & 0.833 & & \\
CP & 0.191 & 0.108 & 0.319 & 0.296 & 0.125 & 0.789 & \\
KC & 0.719 & 0.615 & 0.084 & 0.406 & 0.311 & 0.193 & 0.720 \\
\hline
\end{tabular}

* The diagonal values are alpha scores.

\subsection{Regression Analyses}

In order to test the proposed hypotheses proposed in the research model presented in Figure 1, we employed the method of multiple regression analysis. Two multiple regression analyses were conducted. The first multiple regression analysis was used to test whether perceived user-friendliness, perceived usefulness, organizational rewards, and community of practice are significant predictors of intention to use KM system. The results of this regression analysis are presented in Table 7. The second multiple regression analysis was conducted to predict perceived usefulness based on perceived user-friendliness, organizational rewards, individual factors, management support, and KM system characteristics. Table 8 presents the results of the second regression analysis. Summated scores of the respective factors were used to obtain the scores for all the measures.

Table 7. Regression analysis predicting intention to use KM system

\begin{tabular}{lccccccc}
\hline \multicolumn{7}{c}{ Regression Analysis Predicting ITU } \\
\hline Predictors & Unstd. Coeff. & Std. Coeff. & t-Stat & p-Value & VIF & Hypothesis & Supported? \\
\hline PUF & 0.197 & 0.183 & 2.120 & 0.036 & 1.413 & $\mathrm{H}_{5 \mathrm{~b}}$ & Yes \\
ORR & 0.147 & 0.176 & 2.034 & 0.044 & 1.423 & $\mathrm{H}_{4 \mathrm{~b}}$ & Yes \\
$\mathrm{PU}$ & 0.255 & 0.319 & 3.374 & 0.001 & 1.697 & $\mathrm{H}_{6}$ & Yes \\
$\mathrm{CP}$ & 0.235 & 0.211 & 2.740 & 0.007 & 1.127 & $\mathrm{H}_{7}$ & Yes \\
$\mathrm{R}$ & 0.628 & & & & & & \\
$\mathrm{R}^{2}$ & 0.395 & & & & & & \\
Adjusted $\mathrm{R}^{2}$ & 0.374 & & & & & & \\
\hline
\end{tabular}

Table 8. Regression analysis predicting perceived usefulness

\begin{tabular}{lccccccc}
\hline \multicolumn{7}{c}{ Regression Analysis Predicting PU } \\
\hline Predictors & Unstd. Coeff. & Std. Coeff. & t-Stat & p-Value & VIF & Hypothesis & Supported? \\
\hline PUF & 0.213 & 0.158 & 1.605 & 0.111 & 2.103 & $\mathrm{H}_{5 \mathrm{a}}$ & No \\
ORR & 0.245 & 0.234 & 2.907 & 0.004 & 1.418 & $\mathrm{H}_{4 \mathrm{a}}$ & Yes \\
$\mathrm{IF}$ & 0.080 & 0.068 & 0.943 & 0.348 & 1.123 & $\mathrm{H}_{1}$ & No \\
MS & 0.123 & 0.111 & 1.489 & 0.139 & 1.219 & $\mathrm{H}_{2}$ & No \\
KC & 0.459 & 0.367 & 3.575 & 0.001 & 2.304 & $\mathrm{H}_{3}$ & Yes \\
R & 0.691 & & & & & & \\
$\mathrm{R}^{2}$ & 0.477 & & & & & & \\
Adjusted $\mathrm{R}^{2}$ & 0.454 & & & & & & \\
\hline
\end{tabular}




\subsection{Testing Regression Assumptions}

To test that there is no violation of assumptions underlying the multiple regression analyses, we conducted the runs test, Levene's test and Kolmogorov-Smirnov test. These tests show that the assumptions of randomness, constancy of variance, and normality are not violated. In addition, the VIFs and condition indexes are within acceptable levels (VIFs $<4.00$ and condition indexes $<30.00$ ). Therefore, there is no evidence of multicollinearity.

\section{Discussion, Limitations and Future Direction}

\subsection{Discussion and Implications}

The results show that perceived user-friendliness, perceived usefulness, organizational rewards, and community of practice are significant predictors of intention to use KM systems. The results also show that organizational rewards and KM system characteristics have a positive impact on perceived usefulness. However, the results also show insufficient evidence for support of three hypotheses (H1, H2, and H5a). This suggests that individual factors and management support have no significant influence on perceived usefulness, and that perceived user-friendliness plays insignificant role in predicting perceived usefulness.

The findings suggest that business schools need to focus on usefulness and practical relevance of knowledge captured in knowledge management systems. This is in line with the current debate in management education regarding the appropriateness of methods employed to teach business knowledge (Chia, 2005; Donaldson, 2002; Ghoshal, 2005; Leavitt, 1989; Mintzberg \& Gosling, 2002; Pfeffer \& Fong, 2002; Pfeffer, 2007; Rubin \& Dierdorff, 2009). Organizational rewards being a significant predictor of intention to use KM systems corroborate the expectancy theory. Therefore, it is important for business school to communicate on the usefulness of their KM systems but also to encourage its usage through different incentives. For example, if students perceive that KM systems would make their learning easier or more interesting, they will be more willing to use it.

The "community of practice" (Lave \& Wenger, 1991) construct captures the social and people oriented KM systems. This construct has a direct and positive influence on intention to use KM systems as shown in Table 7. However, one may say that students are willing to use a "community of practice" only if doing so is rewarding, and if it is easy to use and useful. In other words, perceived usefulness, perceived user-friendliness and organizational rewards may be some intermediate variables between the "community of practice" and the intention to use KM systems.

\subsection{Limitations and Future Direction}

There are a number of limitations of this study. First, data have been collected from a convenience sample of students of only one business school. The results from such a sample impose some limitations on the generaligability of the findings. Future research may test and validate the model by collecting data from multiple business schools. Second, though the research model presented in this study is based on the extant literature of the adoption of KM systems, we do not claim that an exhaustive list of factors has been identified. Future research may extend the model by adding constructs that can complement the model. Finally, future studies should consider using qualitative methods such as focus group discussions and case studies to revalidate the model instead of and in addition to quantitative survey method.

\section{References}

Alavi, M., \& Leidner, D. E. (2001). Review: Knowledge management and knowledge management systems: Conceptual foundations and research issues. MIS Quarterly, 25(1), 107-136. http://dx.doi.org/10.2307/3250961

Argyris, C. (1982). Reasoning, learning, and action: Individual and organizational (1st ed.). San Francisco: Jossey-Bass.

Argyris, C., \& Schön, D. A. (1978). Organizational learning. Reading, Mass: Addison-Wesley Pub. Co.

Arntzen, A. A. B., Worasinchai, L., \& Ribiere, V. M. (2009). An insight into knowledge management practices at Bangkok University. Journal of Knowledge Management, 13(2), 127-144. http://dx.doi.org/10.1108/13673270910942745

Badawy, M. K. (1976). The management clinic: Meeting the challenge of relevancy in management education. Academy of Management Review, 1(4), 129-133.

Bénézech, D., Lambert, G., Lanoux, B., Lerch, C., \& Loos-Baroin, J. (2001). Completion of Knowledge 
Codification: An Illustration Through the ISO 9000 Standards Implementation Process. Research Policy, 30(9), 1395-1407. http://dx.doi.org/10.1016/S0048-7333(01)00158-5

Birnik, A., \& Billsberry, J. (2008). Reorienting the business school agenda: The case for relevance, rigor, and righteousness. Journal of Business Ethics, 82(4), 985-999. http://dx.doi.org/10.1007/s10551-007-9607-x

Boyatzis, R. E. (1982). The competent manager: A model for effective performance. New York, NY: John Wiley.

Brown, J. S., \& Duguid, P. (2001). Knowledge and organization: A social-practice perspective. Organization Science, 12, 198-213. http://dx.doi.org/10.1287/orsc.12.2.198.10116

Cannon, M. D., \& Witherspoon, R. (2005). Actionable feedback: Unlocking the power of learning and performance improvement. Academy of Management Perspectives, 19(2), 120-134.

Cataldo, C. G. (2009). Cultivating communities of practice: A guide to managing knowledge. Academy of Management Learning \& Education, 8(2), 301-303. http://dx.doi.org/10.5465/AMLE.2009.41788855

Chia, R. (2005). The aim of management education: Reflections on mintzberg's managers not MBAs. Organization Studies (01708406), 26(7), 1090-1092. http://dx.doi.org/10.1177/017084060502600707

Chia, R., \& Holt, R. (2008). The nature of knowledge in business schools. Academy of Management Learning \& Education, 7(4), 471-486. http://dx.doi.org/10.5465/AMLE.2008.35882188

Chua, A. Y. K., \& Heng, S. K. (2010). A knowledge management perspective on Art Education. International Journal of Information Management, 30, 326-334. http://dx.doi.org/10.1016/j.ijinfomgt.2009.12.002

Cohendet, P., \& Meyer-Krahmer, F. (2001). The theoretical and policy implications of knowledge codification. Research Policy, 30(9), 1563-1591. http://dx.doi.org/10.1016/S0048-7333(01)00168-8

Cortada, J. W., \& Woods, J. A. (Eds.) (2000). The knowledge management yearbook: 2000-2001. Butterworth Heinemann, Boston, MA.

Cowan, R., David, P. A., \& Foray, D. (2000). The explicit economics of Knowledge codification and tacitness. Industrial and Corporate Change, 6(2), 211-253. http://dx.doi.org/10.1093/icc/9.2.211

Davenport, T. H., De Long, D. W., \& Beers, M. C. (1998). Successful knowledge management projects. Sloan Management Review, 39(2), 43-57.

Davis, F. D. (1986). Perceived usefulness, perceived ease of use, and user acceptance of information technology. MIS Quarterly, 13, 318-339.

Davis, F. D., Bagozzi, R. P., \& Warshaw, P. R. (1989). User acceptance of computer technology: A comparison of two theoretical models. Management Science, 35, 982-1003. http://dx.doi.org/10.1287/mnsc.35.8.982

Dewey, J. (1896). The reflex arc concept in psychology. In J. A. Boydston (Ed.), John Dewey: The early works, 1882-1898 (vol. 5, pp. 96-0000000000000109). Carbondale, IL: Southern Illinois University Press.

Donaldson, L. (2002). Damned by our own theories: Contradictions between theories and management education. Academy of Management Learning \& Education, 1(1), 96-106. http://dx.doi.org/10.5465/AMLE.2002.7373701

Ellis, S., \& Davidi, I. (2005). After-event reviews: Drawing lessons from successful and failed experience. Journal of Applied Psychology, 90(5), 857-871. http://dx.doi.org/10.1037/0021-9010.90.5.857

Ensor, J., Cottam, A., \& Band, C. (2001). Fostering knowledge management through the creative work environment: A portable model from the advertising industry. Journal of Information Science, 27(3), 147-155. http://dx.doi.org/10.1177/016555150102700304

Feldman, D. C. (2005). The food's no good and they don't give us enough: Reflections on mintzberg's critique of MBA education. Academy of Management Learning \& Education, 4(2), 217-220. http://dx.doi.org/10.5465/AMLE.2005.17268569

Fenwick, T. (2005). Ethical dilemmas of critical management education: Within classrooms and beyond. Management Learning, 36(1), 31-48. http://dx.doi.org/10.1177/1350507605049899

Friga, P. N., Bettis, R. A., \& Sullivan, R. S. (2003). Changes in graduate management education and new business school strategies for the 21st century. Academy of Management Learning \& Education, 2(3), 233-249. http://dx.doi.org/10.5465/AMLE.2003.10932123

Gaski, J. F., \& Nevin, J. R. (1985). The differential effects of exercised and unexercised power sources in a marketing channel. Journal of Marketing Research, 22(2), 130-142. http://dx.doi.org/10.2307/3151359 
Ghoshal, S. (2005). Bad management theories are destroying good management practices. Academy of Management Learning \& Education, 4(1), 75-91. http://dx.doi.org/10.5465/AMLE.2005.16132558

Glaser, R. (1984). Education and thinking: The role of knowledge. American Psychologist, 39, 93-104. http://dx.doi.org/10.1037/0003-066X.39.2.93

Gray, P. H. (2000). The effects of knowledge management systems on emergent teams: Towards a research

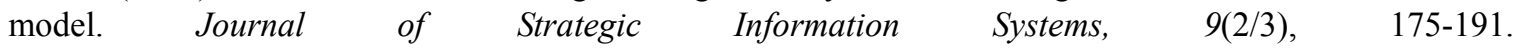
http://dx.doi.org/10.1016/S0963-8687(00)00040-8

Hair, J. F., Anderson, R. E., Tatham, R. L., \& Black, W. C. (2006). Multivariate Data Analysis (6th ed.). Upper Saddle River, NJ: Prentice-Hall.

Hansen, A. H., \& Moussouri, T. (2004). 'Fuzzy' boundaries: Communities of practice and exhibition teams in European natural history museums. Museum and Society, 2(3), 161-174.

Hossain, M. M., \& Prybutok, V. R. (2008). Consumer acceptance of RFID technology: An exploratory study. IEEE Transactions on Engineering Management, 55(2), 316-328. http://dx.doi.org/10.1109/TEM.2008.919728

Huber, G. P. (1991). Organizational learning: The contributing processes and the literatures. Organization Science, 2(1), 88. http://dx.doi.org/10.1287/orsc.2.1.88

Jayanti, R. K., \& Burns, A. C. (1998). The antecedents of preventive health care behavior: An empirical study. $J$. Acad. Market. Sci., 26(1), 6-15. http://dx.doi.org/10.1177/0092070398261002

Johannessen, J. A., Olaisen, J., \& Olsen, B. (2001). Mismanagement of tacit knowledge: The importance of tacit knowledge, the danger of information technology and what to do about it. International Journal of Information Management, 21(1), 3-20. http://dx.doi.org/10.1016/S0268-4012(00)00047-5

Kankanhalli, A., Tan, B. C. Y., \& Wei, K. K. (2005). Contributing knowledge to electronic knowledge repostitories: An empirical investigation. MIS Quarterly, 29(1), 113-143.

Katzenbach, J. R., \& Smith, D. K. (1993). The wisdom of teams: Creating the high-performance organization. Boston, Mass.: Harvard Business School Press.

Kim, D. H. (1993). The Link between individual and organizational learning. Sloan Management Review, 35(1), $37-50$.

Kimble, C., \& Bourdon, I. (2008). Some success factors for the communal management of knowledge. International Journal of Information Management, 28(6), 461-467. http://dx.doi.org/10.1016/j.ijinfomgt.2008.08.007

Lambert, G., \& Lerch, C. (1999). Normes et codification : une étude des référentiels ISO 9000. Revue Française de Gestion Industrielle, 18(4), 63-80.

Lambert, G., \& Ouedraogo, N. (2006). Organiser la création de connaissances en entreprise: une analyse des points de passage organisationnels entre le système de management de la qualité et le knowledge management. In Azan, W., Bares, F., \& Cornolti, C. (Eds.), Logiques de création: enjeux théoriques et management (pp. 59-82).

Lambert, G., \& Ouedraogo, N. (2007). L'approche processus comme vecteur de mutation vers une organisation apprenante: le cas d'une grande banque française. Management International, 11(4), 31-48.

Lave, J., \& Wenger, E. (1991). Situated Learning: Legitimate Peripheral Participation. Cambridge: Cambridge University Press. http://dx.doi.org/10.1017/CBO9780511815355

Leavitt, H. J. (1989). Educating our MBAs: On teaching what we haven't taught. California Management Review, $31(3), 38$.

Lin, C., \& Wu, C. (2005). A knowledge creation model for ISO 9001:2000. Total Quality Management, 16(5), 657-670. http://dx.doi.org/10.1080/14783360500077625

Martínez, Z. L., Toyne, B., \& Menger, R. A. (2000). Research expectations at business schools: Responding to changing business education pressures. Journal of Marketing Management, 16(7), 761-778. http://dx.doi.org/10.1362/026725700784672890

Massey, D. S., Durand, J., \& Malone, N. J. (2002). Beyond Smoke and Mirrors: Mexican Immigration in an Era of Economic Integration. New York: Russell Sage Foundation. 
Mearns, M. A., \& du Toit, A. S. A. (2008). Knowledge audit: Tools of the trade transmitted to tools for tradition. International Journal of Information Management, $28(3), \quad$ 161-167. http://dx.doi.org/10.1016/j.ijinfomgt.2007.09.004

Mintzberg, H., \& Gosling, J. (2002). Educating managers beyond borders. Academy of Management Learning \& Education, 1(1), 64-76. http://dx.doi.org/10.5465/AMLE.2002.7373654

Nonaka, I., \& Konno, N. (1998). The concept of Ba: building a foundation for knowledge creation. California Management Review, 40(3), 40-54. http://dx.doi.org/10.2307/41165942

Nunnally, J. C. (1978). Psychometric Theory (2nd ed.). New York: McGraw-Hill.

Ouedraogo, N. (2007). Impact du management de la qualité sur l'apprentissage organisationnel et la gestion des connaissances. Thèse de doctorat ès Sciences de Gestion, Université Robert Schuman, Strasbourg III.

Palincsar, A. S. (1998). Social constructivist perspectives on teaching and learning. Annual Review of Psychology, 49(1), 345. http://dx.doi.org/10.1146/annurev.psych.49.1.345

Papert, S. (1980). Mindstorms: Children, computers and powerful ideas. New York: Basic Books.

Pearce, C. L. (2004). The future of leadership: Combining vertical and shared leadership to transform knowledge work. Academy of Management Executive, 18(1), 47-57. http://dx.doi.org/10.5465/AME.2004.12690298

Pearce, C. L., Conger, J. A., \& Locke, E. A. (2007). Shared leadership theory. Leadership Quarterly, 18(3), 281-288. http://dx.doi.org/10.1016/j.leaqua.2007.03.009

Pfeffer, J. (2007). A modest proposal: How we might change the process and product of managerial research. Academy of Management Journal, 50(6), 1334-1345. http://dx.doi.org/10.5465/AMJ.2007.28166117

Pfeffer, J., \& Fong, C. T. (2002). The end of business schools? Less success than meets the eye. Academy of Management Learning \& Education, 1(1), 78-95. http://dx.doi.org/10.5465/AMLE.2002.7373679

Piaget, J. (1962). Play, dreams and imitation in childhood. New York: Norton.

Polanyi, M. (1966). The tacit dimension. New York: Double Day.

Rezania, D., \& Henry, M. (2010). Management education: Classifying business curricula and conceptualizing transfers and bridges. International Journal of Business and Management, 5(5), 44-50.

Rowley, J. (2000). Is higher education ready for knowledge management? The International Journal of Educational Management, 14(7), 325-333. http://dx.doi.org/10.1108/09513540010378978

Rubin, R. S., \& Dierdorff, E. C. (2009). How relevant is the MBA? Assessing the alignment of required curricula and required managerial competencies. Academy of Management Learning \& Education, 8(2), 208-224. http://dx.doi.org/10.5465/AMLE.2009.41788843

Tan, W. L., \& Al-Hawamdeh, S. (2001). Knowledge management in the public sector: Principles and practices in police work. Journal of Information Science, 27(5), 311-318. http://dx.doi.org/10.1177/016555150102700502

Trowler, P. (1996). Angels in marble? Accrediting prior experiential learning in higher education. Studies in Higher Education, 21(1), 17. http://dx.doi.org/10.1080/03075079612331381427

Turner, J. R. (1999). The handbook of project-based management: Improving the processes for achieving strategic objectives (2nd ed.). London, New York: McGraw-Hill.

Vroom, V. H. (1964). Work and motivation. New York: Joh0000000000n Willey.

Wenger, E., \& Snyder, B. (2000). Communities of practice: The organizational frontier. Harvard Business Review, 78(1), 139-145.

West, M. A., \& Altink, W. M. M. (1996). Innovation at work: Individual, group, organizational, and socio-historical perspectives. European Journal of Work \& Organizational Psychology, 5(1), 3-12. http://dx.doi.org/10.1080/13594329608414834

Xu, J., \& Quaddus, M. (2005a). Exploring the perceptions of knowledge management systems. The Journal of Management Development, 24(4), 320-334. http://dx.doi.org/10.1108/02621710510591334

$\mathrm{Xu}$, J., \& Quaddus, M. (2005b). From rhetoric towards a model of practical knowledge management systems. The Journal of Management Development, 24(4), 291-319. http://dx.doi.org/10.1108/02621710510591325 